\title{
Gender Differences in Beliefs about English Language Policies (ELPs): The Case of Saudi Higher Education English Departments
}

\author{
Suliman Mohammed Nasser Alnasser* \\ Department of English Language and Literature, College of Arts, King Saud University, Riyadh, Saudi Arabia
}

Corresponding author: Suliman Mohammed Nasser Alnasser, E-mail: smalnasser@ksu.edu.sa

\section{ARTICLE INFO}

Article history

Received: March 2, 2018

Accepted: April 28, 2018

Published: April 30, 2018

Volume: 6 Issue: 2

Conflicts of interest: None

Funding: None

\begin{abstract}
Review of literature suggests that issues in English language policies (ELPs) in higher education foreign language department levels have not been addressed, and the relationship between beliefs about general notions of ELPs and gender has been disregarded. The current study investigates gender-related differences in beliefs on five main notions of ELPs among staff members in Saudi Arabian English departments. An online survey was administered to staff members in different Saudi English departments from different regions in Saudi Arabia. Five general statements on ELPs were included in the survey and were responded to by male $(n=67)$ and female $(n=143)$ staff members (total $=210)$. Pearson's chi-square test of independence and the calculated percentages of responses were used to analyze gender differences. No statistically significant differences were found between male and female participants, with the exception of one statement. Both genders had generally similar beliefs on ELPs. Moreover, the female staff had slightly stronger beliefs than the male staff, and males showed more hesitation than females did when deciding on ELP matters. The study also discusses the implications of the findings and provided recommendations for future research.
\end{abstract}

Key words: Beliefs, Gender Differences, Language Policy, Language Use, Saudi English Departments, Staff Members

\section{INTRODUCTION}

The area of language policy (LP) has been eliciting increasing attention from researchers recently (e.g., Johnson, 2013; Schiffman, 2010; Shohamy, 2006; Spolsky, 2004). Educational language policies have been the focus of policy makers in several countries. In Saudi Arabia, for example, LPs about what foreign language to teach, when to teach it, and how many hours should be dedicated to teaching it have been studied and reviewed continuously. Saudi universities have English language departments where male and female staff members are affiliated with the same institution but work in segregated locations. LPs within these departments already exist or are to be developed in the near future. In this regard, male and female staff members are likely to work together in creating ELPs that both genders will implement. Given the differences between male and female individuals in second/ foreign contexts in terms of beliefs about several educational aspects (Bernat \& Lloyd, 2007; Yilmaz, 2010), an investigation must be conducted to determine if such differences are present among educated staff members in Saudi's higher education English departments. The lack of investigation in this area has created gaps in our understanding of gender-related differences in relation to general notions of ELPs. The study aims to examine how similar or different female beliefs are from those of male staff members with regard to five general notions of ELPs.

\section{THEORETICAL BACKGROUND}

\section{Language Beliefs}

The current study investigates the relationship between gender and beliefs about ELPs; therefore, beliefs and their relation to language use need to be discussed. Richardson (1996: 102) defined beliefs as "psychologically held understandings, premises, or propositions about the world that are felt to be true." An individual's belief system, metacognition, and social cognition empower intellectual performance (Schoenfeld, 1983). Beliefs influence thinking, learning, solving problems, and reasoning (Kardash \& Scholes, 1996) and considerably affect an individual's attitudes, views, and cognition (Ozdemir, 2013). Furthermore, beliefs, whether negative or positive, can guide the manner through which people respond to a language in terms of learning, motivation, use, and so on (Bernat \& Lloyd, 2007). Ricento (2013) explained that in a particular context, individual beliefs can lead to the creation of a framework that can eventually lead to an ideology. Ideology is defined as "the shared framework(s) of social beliefs that organize and coordinate the 
social interpretations and practices of groups and their members" (Van Dijk, 1998: 8). Ideology can considerably affect the formation of identities, learning, practices, and systems in educational contexts (Blommaert, 2006).

\section{Language Policy}

LPs are being created constantly around the world. A reason for the need for LPs is that several countries use more than one language in their various sub-communities. For example, more than 10 languages, including Afrikaans, English, and other indigenous languages, are used in South Africa. Controlling the use of these languages requires policy makers to make decisions on several issues, such as which language should be formalized, which language/s to teach in schools, and which language/s to use for public signs. LPs can exert an effect at the national or local (small communities) level. LPs can also exist in a work community where two or more languages are being used by members, such as foreign language academic departments. LP categories must be established and described to provide readers an overall concept of the field.

Literature offers several definitions of LP. The definitions given by Keplan and Baldauf (1997) and Cooper (1989) provide a vivid description of the concept. Keplan and Baldauf stated that "the exercise of language planning leads to, or is directed by, the promulgation of a language policy by the government (or other authoritative body or person). A language policy is a body of ideas, laws, regulations, rules and practices intended to achieve the planned language change in societies, groups, or systems" (1997: xi). Cooper defined LP as "deliberate efforts to influence the behavior of others with respect to the acquisition, structure, or functional allocation of their language codes" (1989: 45). Spolsky (2004) suggested that LP has three components: how a community practices a language, intentional changes to how a current language is being practiced, and what beliefs and ideologies are held on the use of a language.

According to Johnson (2013), LPs can be classified into categories. The first category is concerned with the genesis of LPs. Policies can be at the macro level (top-down), created by higher authorities, and passed on to lower bodies to be abided by and practiced. LPs can also be at the micro level (bottom-up) and created by lower bodies. Such policies can be made at the local level by a small community that will have direct contact with the LPs and can either be kept at their level or passed on to higher authorities for approval or even for generalization. An example of micro-level policies would be those made at institutional levels and do not affect other similar institutions outside their authority.

Another category pertains to the means and goals of LPs. LPs can be either overt or covert. Policies that are announced to the public are referred to as overt policies (Johnson, 2013; Schiffman, 2010; Shohamy, 2006). For certain policies to succeed and be followed, they need to be announced to the community/ies so they are known and practiced in the way they are intended. An example of a covert policy is when a government creates policies concerning a particular language used in its communities and wishes to limit its use without provoking its speakers. The government may take indirect actions to achieve these policies without alerting the community of the new LPs being adopted.

LPs can also be classified according to their documentation. Documentation of policies refers to the level of their formality (Johnson, 2013; Schiffman, 1996). In other words, documentation of policies can be explicit, that is, policies are documented in a way (spoken or written) that makes them official and resilient to change. Documentation can also be implicit, which refers to LPs occurring informally (e.g., by members of the community) and without official approval by policy makers or communities (Johnson, 2013; Schiffman, 1996). Explicit LPs are viewed as official and therefore to be abided by, whereas implicit policies are regarded as non-official and may be violated and altered.

\section{English Language in Saudi Arabia}

Language planning in any country has two main types, which are acquisition and status planning (Ferguson, 1968; Haugen, 1983; Hornberger, 2006). These types have been referred to as language planning dimensions (Bright, 1992). The former refers to actions and policies being made to serve the learning and teaching of a particular language. The latter refers to the status of a language in a country with regard to whether or not it is an official language to be used in certain contexts (c.f. Wardhaugh \& Fuller, 2015). Status planning involves dealing with "initial choice of language, including attitudes toward alternative languages and the political implications of various choices" (Bright, 1992: 311).

In the Saudi context, not only is Arabic the only formal language used in the country, but Arabic is looked at as a holy language because it is the language of the Muslims' holy book (Quran) (Fishman, 2002; Liddicoat: 2012; Payne \& Almansour, 2014) and the language used in Saudi's land for over a thousand years. Liddicoat (2012) suggested that several countries could adopt religious planning, in which a country treats a holy language with special attention and promotes its use whenever possible. Although no reference to other languages is made in the Saudi constitution, the Saudi government has been devoting increasing attention to the English language recently (in other words, English has been accorded a high status). In Saudi's educational policy, English is the only foreign language the government is focusing on ${ }^{1}$.

With regard to Saudi acquisition planning, the government wishes to teach the English language, which is being introduced and taught at all educational levels (Alasmari \& Khan, 2014) even though the Saudi constitution does not mention teaching other languages. The introduction of English at the elementary level (initially the sixth grade) provoked the community in the past. In reference to this introduction, the government set in place covert LPs to introduce the English language, knowing that the community might oppose the move. This strategy was followed by successful gradual introduction to the fifth and fourth elementary levels.

With regard to status planning, observing the different domains in the Saudi context indicates that English has been accorded high status. Although the Saudi constitution does not have a reference for the English language, English is used in many formal (political and non-political) occasions. For exam- 
ple, official Saudi television and radio channels are in Arabic (the formal language of the country) and English² (a foreign language). Moreover, official public signs are being written in Arabic and, in many occasions, English. Formal letters used by almost every institution in the country are given titles of the institution's identity and logo in Arabic and English.

A number of examples can be provided in relation to acquisition and status planning, but the question that arises here is this: why has the English language (and not other languages) been receiving the government's attention for the last two decades and why is its status still growing? The number of foreign nationals in Saudi Arabia who speak languages other than Arabic and English is greater than those who speak English, and yet their languages have not attracted the attention of the Saudi government. The government's interest in the English language could be due to certain political reasons. Another reason could be the fact that English is used globally as a lingua franca, and the government might be using it for communication with other communities (c.f. Firth, 1996; Seidlhofer, 2005). In support of this argument, the Saudi government is on the verge of changing its economic policies to attract international investments, and the English language is viewed as a means to achieve this purpose. The discussion of how English is regarded in Saudi Arabia may justify current gender beliefs on ELPs held by staff in English departments.

\section{Gender and Language Use}

A survey of literature suggests that studies on LPs have not addressed the existence of gender differences in relation to beliefs on LPs. Investigating the differences between males and females has elicited the interest of many researchers in the last three decades. Research on psychology has investigated the relationship among gender, cognition, behavior, and verbal performance, and the results revealed significant gender-related differences in these aspects (Bacon \& Finnemann, 1992). Moreover, studies on gender in educational and non-educational contexts have indicated differences between males and females.

Numerous studies have also examined differences between males and females in terms of language use. For example, Tannen (1995) suggested that males and females demonstrate different interactive patterns, in which males adopt a direct style in interacting with other individuals, whereas females adopt an indirect style. Herring (2000) posited that differences in language use can be observed between the two genders in several speech features, such as use of profanity and degree of engagement. In addition, males are more assertive in their speech and written text than females (Herring, 2000; Leaper \& Ayres, 2007). Males are also less concerned with politeness than females are when communicating with other individuals (Herring, 2000; Savicki, 1996). Furthermore, females "self-disclose" when writing informal messages (Savicki, 1996) and are likely to show more appreciation and be more apologetic than males (Herring, 2000). Newman et al. (2008) examined differences in language use in discourse produced by the two genders and concluded that "women used more words related to psychological and so- cial process" and that "men referred more to object properties and impersonal topics" (211).

The preceding discussion suggests that males and females are different in terms of language use. However, most studies examined language use by sampling individuals who are not well-educated and affiliated with academic institutions. In other words, they disregarded gender differences in language use among educated individuals who are affiliated with academic institutions, such as English departments. Therefore, the current study attempts to investigate this area to reach an understanding of whether or not such differences exist among male and female staff members who are affiliated with Saudi English departments.

\section{Study}

The current study aims to explore the relationship between gender and the beliefs on ELPs of Saudi English departments' staff members. Specifically, the study investigated whether a difference exists between male and female staff in terms of their beliefs on five main ELP notions. A quantitative approach was adopted to obtain data through an online survey.

\section{Research Question and Null Hypotheses}

The research question addressed in the study is as follows: How similar/different are the ELP beliefs of Saudi male and female staff members in English departments?

The following null hypotheses were tested

1. No statistically significant difference exists between Saudi male and female staff members'beliefs on whether or not their English departments must have ELPS.

2. No statistically significant difference exists between Saudi male and female staff members' beliefs on whether or not staff members should abide by department ELPS.

3. No statistically significant difference exists between Saudi male and female staff members'beliefs on whether or not staff members' familiarity with ELPs contributes to the accomplishment of institutional goals.

4. No statistically significant difference exists between Saudi male and female staff members'beliefs on whether or not institutions should require their English departments to have ELPs.

5. No statistically significant difference exists between Saudi male and female staff members' beliefs on whether or not ELPs should be monitored by the chairman.

\section{METHOD}

\section{Participants}

The participants were 210 staff members (143 females and 67 males) working for Saudi English departments. However, maintaining the same number of participants for each gender was impossible due to the nature of the study and the sampling approach (that is, participation in the study was voluntary). The participants were affiliated with departments in different regions of Saudi Arabia and were of different ranks, ranging from 
teaching assistants (holding BA degrees) to full professors. They also held different degrees in subject areas of concern in English departments (e.g., linguistics, literature, and translation).

\section{Online Survey}

An online survey was performed to obtain data for testing the study's five hypotheses. The survey was refereed by several researchers prior to its administration to ensure its appropriateness for the study. A few comments and recommendations were provided and considered because they contributed to the validity of the survey. The survey allowed the inclusion of staff members working in different regions in the country. Participants could complete the online survey by using any device with access to the Internet. The purpose of the study and the key words used were explained in the beginning of the survey. A section about the participants' background was included. The survey had five items (statements), each of which corresponds to one of the null hypotheses of the study. A Likert scale (strongly agree, agree, not sure, disagree, and strongly disagree) was adopted for each of the five items.

\section{RESULTS}

The data were calculated in the form of frequencies and percentages. The null hypotheses were tested using Pearson's chi-square test of independence to investigate the significance of gender differences, if any.

\section{Null Hypothesis (1): No statistically significant difference exists between Saudi male and female staff members' beliefs on whether or not their English departments must have ELPs.}

Corresponding item: Having departmental language policies about when to use English is a must.

Overall, the majority of the respondents either strongly agreed or agreed with the necessity of having ELPs in English departments (Table 1). A few of the respondents were uncertain (not sure) or disagreed with the notion. Examination of the data suggested a slight difference between male and female staff members' beliefs on the notion. In detail, the difference between male and female respondents who strongly agreed with the given statement was $6.59 \%$, with the higher percentage being reported by female respondents. Moreover, the difference between male and female respondents who agreed with the notion was $0.16 \%$, with the higher percentage being reported by male respondents. With regard to not being sure about the statement, a difference of $7.65 \%$ was observed between male and female responses, with the higher percentage being reported by male respondents. As to disagreeing with the statement, a $1.21 \%$ difference was found, with the higher percentage being reported by female respondents. None of the respondents strongly disagreed with the statement.

Pearson's chi-square test of independence was run on the data and revealed no statistically significant difference $(p=0.131)$ between the male and female participants' responses (Table 2). Hence, the null hypothesis is accepted, given that no statistically significant difference was found between male and female staff members' beliefs about having ELPs. Nevertheless, the data suggested that female staff members had slightly stronger beliefs than male members and that uncertainty among male staff members was slightly greater than that among female members.

\section{Null Hypothesis (2): No statistically significant} difference exists between Saudi male and female staff members' beliefs on whether or not staff members should abide by department ELPs

Corresponding item: Members of a department should abide by its English language policies.

Overall, the majority of the respondents either strongly agreed or agreed with the notion that staff members should abide by department ELPs (Table 3). A few respondents were either uncertain (not sure) or disagreed with the notion. Thorough examination of the data suggested a difference between male and female staff members' beliefs about this notion. In detail, the difference between male and female

Table 1. Necessity of having ELPs

\begin{tabular}{lccccc}
\hline \multirow{2}{*}{ Value } & \multicolumn{2}{c}{ Frequency } & & \multicolumn{2}{c}{ Percent } \\
\cline { 2 - 3 } \cline { 5 - 6 } & Male & Female & & Male & Female \\
\hline Strongly agree & 34 & 82 & & 50.75 & 57.34 \\
Agree & 24 & 51 & & 35.82 & 35.66 \\
Not sure & 7 & 4 & & 10.45 & 2.80 \\
Disagree & 2 & 6 & & 2.99 & 4.20 \\
Strongly disagree & 0 & 0 & & 0 & 0 \\
Total & 67 & 143 & & 100 & 100 \\
Grand total & 210 & & & & \\
\hline
\end{tabular}

Table 2. Chi-square tests

\begin{tabular}{lccc}
\hline & Value & df & $\begin{array}{c}\text { Asymptotic } \\
\text { significance (2-sided) }\end{array}$ \\
\hline $\begin{array}{l}\text { Pearson's } \\
\text { chi-square }\end{array}$ & $5.633^{\mathrm{a}}$ & 3 & 0.131 \\
Likelihood ratio & 5.196 & 3 & 0.158 \\
$\begin{array}{l}\text { Linear-by-linear } \\
\text { association }\end{array}$ & 1.099 & 1 & 0.294 \\
N of valid cases & 210 & & \\
\hline
\end{tabular}

Table 3. Abiding by ELPs

\begin{tabular}{lccccc}
\hline Value & \multicolumn{2}{c}{ Frequency } & & \multicolumn{2}{c}{ Percent } \\
\cline { 2 - 3 } \cline { 5 - 6 } & Male & Female & & Male & Female \\
\hline Strongly agree & 30 & 87 & & 44.78 & 60.84 \\
Agree & 27 & 48 & & 40.30 & 33.57 \\
Not sure & 8 & 5 & & 11.94 & 3.50 \\
Disagree & 2 & 3 & & 2.99 & 2.10 \\
Strongly disagree & 0 & 0 & & 0 & 0 \\
Total & 67 & 143 & & 100 & 100 \\
Grand total & 210 & & & & \\
\hline
\end{tabular}


respondents who strongly agreed with the given statement was $16.06 \%$, with the higher percentage being reported by female respondents. Moreover, the difference between male and female respondents who agreed with the notion was $6.73 \%$, with the higher percentage being reported by male respondents. With regard to not being sure about the statement, a difference of $8.44 \%$ was found between male and female responses, with the higher percentage being reported by male respondents. As to disagreeing with the statement, a $0.89 \%$ difference was found, with the higher percentage being reported by male respondents. None of the respondents strongly disagreed with the statement.

Pearson's Chi-square test of independence was run on the data and revealed a statistically significant difference ( $p=0.044)$ between the male and female participants' responses (Table 4). The null hypothesis is therefore rejected, and the alternative hypothesis, which posits that a statistically significant difference exists between male and female staff members in their beliefs on whether or not ELPs should be abided by, is accepted. Among the differences between genders in the reported data, the difference in "strongly agree" contributed the most to the significant difference in responses. Specifically, $44.78 \%$ of the male respondents as opposed to $60.84 \%$ of the female respondents (with a difference of $16.06 \%$ ) strongly agreed with the notion. This result is in line with our earlier speculation that female staff members have stronger beliefs than male staff members.

\section{Null Hypothesis (3): No statistically significant difference exists between Saudi male and female staff members' beliefs on whether or not staff members' familiarity with ELPs contributes to the accomplishment of institutional goals}

Corresponding item: Staff members'familiarity with department language policies contributes to accomplishing institutional goals.

Overall, the majority of the respondents strongly agreed or agreed with the notion that staff familiarity with ELPs helps in achieving institutional goals (Table 5). A few of the respondents were either uncertain (not sure) or disagreed with the notion. Thorough examination of the data suggested a slight difference between male and female staff members' beliefs about the notion. In detail, the difference between male and female respondents who strongly agreed with the given statement was $9.26 \%$, with the higher percentage being reported by female respondents. Moreover, the difference between male and female respondents who agreed with the notion was $0.62 \%$, with the higher percentage being reported by male respondents. With regard to not being sure about the statement, a difference of $7.74 \%$ was found between male and female responses, with the higher percentage being reported by male respondents. As to disagreeing with the statement, a $0.89 \%$ difference was found, with the higher percentage being reported by male respondents. None of the respondents strongly disagreed with the statement.

Pearson's chi-square test of independence was run on the data and revealed that no statistically significant difference ( $p=$
0.167 ) exists between male and female participants' responses (Table 6). Hence, the null hypothesis is accepted, given that no statistically significant difference was found between male and female staff members in terms of familiarity with ELPs and its role in accomplishing institutional goals. Nevertheless, the data suggested that Saudi female staff members had slightly stronger beliefs than males and that uncertainty among the male staff members was slightly greater than that among females.

\section{Null Hypothesis (4): No statistically significant} difference exists between Saudi male and female staff members' beliefs on whether or not institutions should require their English departments to have ELPs

Corresponding item: My institution should require our department to have clear language policies regarding English use.

Overall, the majority of the respondents either strongly agreed or agreed with the notion that institutions (such as universities and colleges) should require their English departments to have ELPs (Table 7). A few of the respondents were either uncertain (not sure) or disagreed with the notion. Thorough

Table 4. Chi-square tests

\begin{tabular}{lccc}
\hline & Value & df & $\begin{array}{c}\text { Asymptotic } \\
\text { significance (2-sided) }\end{array}$ \\
\hline $\begin{array}{l}\text { Pearson's } \\
\text { chi-square }\end{array}$ & $8.097^{\mathrm{a}}$ & 3 & 0.044 \\
Likelihood ratio & 7.708 & 3 & 0.052 \\
Linear-by-linear & 6.103 & 1 & 0.013 \\
aqssociation & & & \\
N of valid cases & 210 & & \\
\hline
\end{tabular}

Table 5. Familiarity with ELPs contributes to achieving goals

\begin{tabular}{lccccc}
\hline \multirow{2}{*}{ Value } & \multicolumn{2}{c}{ Frequency } & & \multicolumn{2}{c}{ Percent } \\
\cline { 2 - 3 } \cline { 5 - 6 } & Male & Female & & Male & Female \\
\hline Strongly agree & 28 & 73 & & 41.79 & 51.05 \\
Agree & 29 & 61 & & 43.28 & 42.66 \\
Not sure & 8 & 6 & & 11.94 & 4.20 \\
Disagree & 2 & 3 & & 2.99 & 2.10 \\
Strongly disagree & 0 & 0 & & 0 & 0 \\
Total & 67 & 143 & & 100 & 100 \\
Grand total & 210 & & & & \\
\hline
\end{tabular}

Table 6. Chi-square tests

\begin{tabular}{lccc}
\hline & Value & df & $\begin{array}{c}\text { Asymptotic } \\
\text { significance (2-sided) }\end{array}$ \\
\hline Pearson chi-square & 5.073 & 3 & 0.167 \\
Likelihood ratio & 4.751 & 3 & 0.191 \\
Linear-by-linear & 3.149 & 1 & 0.076 \\
Association & & & \\
N of valid cases & 210 & & \\
\hline
\end{tabular}


examination of the data suggested a slight difference between male and female staff members' beliefs about this notion. In detail, the difference between male and female respondents who strongly agreed with the given statement was $10.19 \%$, with the higher percentage being reported by female respondents. Moreover, the difference between male and female respondents who agreed with the notion was $3.65 \%$, with the higher percentage being reported by male respondents. With regard to not being sure about the statement, a difference of $6.42 \%$ was found between male and female responses, with the higher percentage being reported by male respondents. As to disagreeing with the statement, a $0.09 \%$ difference was found, with the higher percentage being reported by male respondents. None of the respondents strongly disagreed with the statement.

Pearson's Chi-square test of independence was run on the data and revealed no statistically significant difference $(p=0.174)$ between male and female participants' responses (Table 8). Hence, the null hypothesis is accepted, given that no statistically significant difference was found between male and female staff members in terms of requiring English departments to have ELPs. Nevertheless, the data suggested that Saudi female staff members had slightly stronger beliefs than males and that uncertainty among the male staff members was slightly greater than that among females.

\section{Null Hypothesis (5): No statistically significant} difference exists between Saudi male and female staff members' beliefs on whether or not department ELPs should be monitored by the chairman

Corresponding item: The head of my department should ensure that ELPS are put into practice.

Overall, the majority of the respondents either strongly agreed or agreed with the notion that the chairman should ensure that ELPs are put into practice (Table 9). A few of the respondents were either uncertain (not sure) or disagreed with the notion. Thorough examination of the data suggested a slight difference between male and female staff members' beliefs about this notion. In detail, the difference between male and female respondents who strongly agreed with the given statement was $8.42 \%$, with the higher percentage being reported by female respondents. Moreover, the difference between male and female respondents who agreed with the notion was $2.77 \%$, with the higher percentage being reported by male respondents. With regard to not being sure about the statement, a difference of $6.23 \%$ was found between male and female responses, with the higher percentage being reported by male respondents. As to disagreeing with the statement, a $0.61 \%$ difference was found, with the higher percentage being reported by female respondents. None of the respondents strongly disagreed with the statement.

Pearson's chi-square test of independence was run on the data and revealed no statistically significant difference ( $p=0.307)$ between the male and female participants' responses (Table 10). Hence, the null hypothesis is accepted, given that no statistically significant difference was found between male and female staff members in terms of whether or not they feel that the chairman should ensure the practice of ELPs. Nevertheless, the data suggested that Saudi female
Table 7. Requirement of ELPs

\begin{tabular}{lccccc}
\hline Value & \multicolumn{2}{c}{ Frequency } & & \multicolumn{2}{c}{ Percent } \\
\cline { 2 - 3 } \cline { 5 - 6 } & Male & Female & & Male & Female \\
\hline Strongly agree & 33 & 85 & & 49.25 & 59.44 \\
Agree & 24 & 46 & & 35.82 & 32.17 \\
Not sure & 9 & 10 & & 13.41 & 6.99 \\
Disagree & 1 & 2 & & 1.49 & 1.40 \\
Strongly disagree & 0 & 0 & & 0 & 0 \\
Total & 67 & 143 & & 100 & 100 \\
Grand total & 210 & & & & \\
\hline
\end{tabular}

Table 8. Chi-square tests

\begin{tabular}{lccc}
\hline & Value & df & $\begin{array}{c}\text { Asymptotic } \\
\text { significance (2-sided) }\end{array}$ \\
\hline $\begin{array}{l}\text { Pearson's } \\
\text { Chi-Square }\end{array}$ & $4.977^{\mathrm{a}}$ & 3 & 0.174 \\
Likelihood ratio & 5.388 & 3 & 0.146 \\
$\begin{array}{l}\text { Linear-by-linear } \\
\text { association }\end{array}$ & 2.154 & 1 & 0.142 \\
N of valid cases & 210 & & \\
\hline
\end{tabular}

Table 9. Chairman ensuring the practice of ELPs

\begin{tabular}{lccccc}
\hline \multirow{2}{*}{ Value } & \multicolumn{2}{c}{ Frequency } & & \multicolumn{2}{c}{ Percent } \\
\cline { 2 - 3 } \cline { 5 - 6 } & Male & Female & & Male & Female \\
\hline Strongly agree & 37 & 91 & & 55.22 & 63.64 \\
Agree & 22 & 43 & & 32.84 & 30.07 \\
Not sure & 7 & 6 & & 10.43 & 4.20 \\
Disagree & 1 & 3 & & 1.49 & 2.10 \\
Strongly disagree & 0 & 0 & & 0 & 0 \\
Total & 67 & 143 & & 100 & 100 \\
Grand total & 210 & & & & \\
\hline
\end{tabular}

Table 10. Chi-square tests

\begin{tabular}{lccc}
\hline & Value & df & $\begin{array}{c}\text { Asymptotic } \\
\text { significance (2-sided) }\end{array}$ \\
\hline $\begin{array}{l}\text { Pearson's } \\
\text { chi-square }\end{array}$ & $3.611^{\mathrm{a}}$ & 3 & 0.307 \\
$\begin{array}{l}\text { Likelihood ratio } \\
\text { Linear-by-linear }\end{array}$ & 3.403 & 3 & 0.334 \\
$\begin{array}{l}\text { association } \\
\text { N of valid cases }\end{array}$ & 210 & 1 & 0.194 \\
\hline
\end{tabular}

staff members had slightly stronger beliefs than males and that uncertainty among the male staff members was slightly greater than that among females. However, these slight differences are not statistically significant.

\section{DISCUSSION AND IMPLICATIONS}

The focus of this study is on investigating the similarities/ differences between Saudi male and female staff members' 
beliefs on five main notions of departmental ELPs. Data analysis revealed that male and female staff members have similar beliefs. The male and female staff reported similar responses to the four given survey items (i.e., similar responses to four ELPs notions). The general findings of the current study suggest that ELPs must be maintained in Saudi English departments. This notion is apparent because the majority of the participants, males and females, agreed with the importance of ELPs and believed that abiding by them can lead to positive impacts on their institutions. Additionally, the majority of the participants reported their beliefs that English departments should be required to have ELPs and that their practice should be monitored by the chairman. These findings suggest that staff members of Saudi English departments realize the importance and necessity of having ELPs. An example of their importance is when a non-Arabic-speaking staff member is present in a department meeting where high-stake decisions are being made. Several members may use Arabic (L1) in the discussions, in which case the non-Arabic-speaking member would not understand the message being conveyed and would be unable to participate in decision making. Setting clear LPs on when to use English can prevent such an instance.

An interesting finding is that the female staff showed slightly stronger beliefs than the male staff. For example, the number female staff who strongly agreed with the importance of having ELPs (statement 1) was higher than the number of male staff who reported the same degree of agreement (male $=50.76 \%$; female $=57.39 \%$ ). This result was obtained in all five items; however, the difference found between male and female staff was statistically significant in one item only. When participants responded to the item "members of a department should abide by its English language policies," the difference between female and male staff responses was significant and had a $p$ value of 0.044 . Specifically, $44.78 \%$ of the male participants strongly agreed with the statement, as opposed to $60.84 \%$ of the female participants who reported the same degree of agreement. The difference between the male and female responses was $16.06 \%$, which tested significant. This finding suggests that female staff are more likely to demonstrate commitment to adhering to rules than males. This result might also imply that male members show leniency with regard to following regulations, whereas females are strict and adopt a "by the book" approach when dealing with ELPs.

Another interesting finding is that the reluctance of male staff to make decisions concerning ELPs is greater than that of females, as shown by the higher proportion of male respondents choosing "not sure" across all five items. However, the differences were not statistically significant. This result is consistent with the earlier finding that suggests that females have slightly stronger beliefs than males. In other words, given that female staff have slightly stronger beliefs than males, they are likely to be more confident and less hesitant to make a decision. This finding implies that female staff are firmer, more earnest, and need less time when making decisions (because they are less hesitant) compared with male staff.

In light of the findings of the study, it is argued that female staff can demonstrate similar, if not slightly better, administrative skills at the department level as male staff, and they are likely to be more committed to abiding by regulations. For quite some time, Saudi culture has underestimated the administrative capabilities of women. Most decision-making positions have been assigned to male members of the community. In this regard, female staff in Saudi English departments are likely to be given key positions (such as chairing departments) only when no male staff are present in the work community, which means that male staff are given priority in leadership. In the last three years, policies have begun to shift toward empowering women by allowing for increased involvement in administrative positions. With regard to female staff chairing English departments instead of males, the findings of the study suggest that women have the capability of assuming this role in a very professional manner. However, a question that arises is this: if female members were to head English Departments given the tendency of male staff to be more lenient toward abiding by rules, would such a situation cause a gender-based conflict? This question does not suggest that the researcher is against or in favor of changing the current practice. The researcher believes that selection of a chairperson should go through a voting system (regardless of the nominees' genders). Moreover, administrative skills and expertise (not gender) should be the criteria for selecting a nominee for chairing a department or for occupying other positions.

\section{CONCLUSION}

The study investigated gender-related differences in terms of beliefs about five general notions of ELPs. The overall findings revealed that male and female staff members share similar beliefs. Specifically, the findings showed that males and females share similar beliefs about four ELPs notions, which are necessity of ELPs in English departments, staff members' familiarity with ELPs can be beneficial to accomplishing institutional goals, institutions should require English departments to have ELPs, and the chairman should ensure the practice of ELPs at the department level. Furthermore, the findings revealed significant differences in the fifth notion (i.e., staff members' beliefs on whether or not they should abide by departments' ELPs).

Furthermore, it is found that both genders realize the importance of having ELPs. Therefore, departments that do not have ELPs or desire to update existing ones can allow both genders to collaborate and create an appropriate framework that is accepted by the majority of the staff. The findings also suggested that females have stronger beliefs than males, and males show more hesitation in making decisions than females do. Additionally, the study revealed the possibility for the existence of gender differences in relation to administrative performance; however, reaching a conclusion in this regard requires further research.

Although this study produced interesting findings, the research employed a general scale for testing gender differences. Future research is encouraged to tackle other areas in relation to gender and ELPs, such as what types of ELPs each gender prefers and the relationship between gender and ELPs used inside the classroom. An empirical investigation could also be performed on how similar and different male and female staff are in relation to their administrative skills and leniency in abiding by regulations. 


\section{ACKNOWLEDGMENT}

I would like to thank two anonymous reviewers for their incisive comments that led to the improvement of the manuscript.

\section{END NOTES}

1. Several Saudi universities may offer courses in other languages, such as French and German, but they do not seem to be widely accepted by the public.

2. Broadcasts in languages other than English have been made for short periods but were terminated after launching.

\section{REFERENCES}

Alasmari, A. \& Khan, S., (2014). World Englishes in the EFL Teaching in Saudi Arabia. Arab World English Journal, 5(1), 316-325.

Bacon, S. M. C. \& Finnemann, M.D., (1992). Sex Differences in Self-reported Beliefs about Language Learning and Authentic Oral and Written Input. Language Learning, 42(4), 471-495.

Bernat, E. \& Lloyd, R., (2007). Exploring the Gender Effect on EFL Learners' Beliefs about Language Learning. Australian Journal of Educational \& Developmental Psychology, 7, 79-91.

Blommaert J., (2006). Language Policy and National Identity. In T. Ricento (Ed.). An Introduction to Language Policy: Theory and Method (pp. 238-54). Malden, MA: Blackwell.

Bright, W., (1992). Language Policy. International Encyclopedia of Linguistics, 4, 310-311.

Cooper, R. L., (1989). Language Planning and Social Change. Cambridge, England: Cambridge University Press.

Ferguson, C. A., (1968). Language Development. In J. A. Fishman, C. A., Ferguson, \& J. Dasgupta (Eds.). Language Problems of Developing Nations (pp. 29-97). New York; London: Wiley.

Firth, A., (1996). The Discursive Accomplishment of Normality on "Lingua Franca" English and Conversation Analysis. Journal of Pragmatics, 26, 237-59.

Fishman, J. A., (2002). Holy Languages' in the Context of Societal Bilingualism. Contributions to the Sociology of Language, 87, 15-24.

Haugen, E., (1983). The Implementation of Corpus Planning: Theory and Practice. In J. Cobarrubias \& J. A. Fishman (Eds.). Progress in Language Planning: International Perspectives (pp. 269-290). Berlin; New York: Mouton Publishers.

Herring, S. C., (2000). Gender Differences in CMC: Findings and Implications. Computer Professionals for Social Responsibility Journal, 18(1).

Hornberger, N., (2006). Frameworks and Models in Language Policy and Planning. In T. Ricento (Ed.). An Introduction to Language Policy: Theory and Method (pp. 24-41). Malden, MA: Blackwell Pub.

Johnson, D. C., (2013). Language Policy, Hampshire: Macmillan, UK.

Kaplan, R. B. \& Baldauf, R. B., (1997). Language Planning: From Practice to Theory. Clevedon: Multilingual Matters Ltd.
Kardash, D. A. \& Scholes, R. J., (1996). Effects of Pre-existing Beliefs, Epistemological Beliefs, and Need for Cognition on Interpretation of Controversial Issues. Journal of Educational Psychology, 88(2), 260-271.

Leaper, C. \& Ayres, M., (2007). A Meta-Analytic Review of Gender Variations in Adults' Language Use: Talkativeness, Affiliative Speech, and Assertive Speech. Personality and Social Psychology Review, 11(4), 328-363.

Liddicoat, A. J., (2012). Language Planning as an Element of Religious Practice. Current Issues in Language Planning, 13(2), 121-144.

Newman, M., Groom, C., Handelman, L. \& Pennebaker, J., (2008). Gender Differences in Language Use: An Analysis of 14,000 Text Samples. Discourse Processes, 45, 211-236.

Ozdemir, G., (2013). Erasumus Exchange Students' Beliefs about Language Learning. Procedia Social and Behavioral Sciences, 70, 686-690.

Payne, M. \& Almansour, M., (2014). Foreign Language Planning in Saudi Arabia: Beyond English. Current ISsues in Language Planning, 15(3), 327-342.

Ricento, T., (2013). Language Policy, Ideology and Attitudes in English-Dominant Countries. In R. Bayley, R. Cameron, \& C. Lucas (Eds.). The Oxford Handbook of Sociolinguistics (pp. 525-543). Oxford: Oxford University Press.

Richardson, V., (1996). The Role of Attitudes and Beliefs in Learning to Teach. In J. Sikula, T. J. Buttery, \& E. Guyton (Eds.). Handbook of Research on Teacher Education (pp.102-109). New York, NY: Macmillan.

Savicki, V., Lingenfelter, D. \& Kelley, M., (1996). Gender Language Style and Group Composition in Internet Discussion Groups. Journal of Computer-Mediated Communication, 2(3).

Schiffman, H. F. (1996). Linguistic Culture and Language Policy. London: Routledge.

Schiffman, H.F., (2010). South and Southeast Asia. In J. A. Fishman \& O. Garcia (Eds.). Handbook of Language and Ethnic Identity: Disciplinary and Regional Perspectives (pp. 452-469). Oxford: Oxford University Press.

Schoenfeld, A. H., (1983). Beyond the Purely Cognitive: Belief Systems, Social Cognitions, and Metacognitions as Driving Forces in Intellectual Performance. Cognitive Science, 7, 329-363.

Seidlhofer, B., (2005). English as a Lingua Franca. ELT Journal, 59(4), 339-341.

Shohamy, E., (2006). Language Policy: Hidden Agendas and New Approaches. London and New York: Routledge.

Spolsky, B., (2004). Language Policy. Cambridge: Cambridge University Press.

Tannen, D., (1995). Gender and Discourse. Oxford: Oxford University Press.

Van Dijk T. A., (1998). Ideology: A Multidisciplinary Approach. London: Sage.

Wardhaugh, R. \& Fuller, J. M., (2015). An Introduction to Sociolinguistics. (Seventh edition). Chichester: Wiley Blackwell.

Yilmaz, C., (2010). The Relationship between Language Learning Strategies, Gender, Proficiency and Self-Efficacy Beliefs: A Study of ELT Learners in Turkey. Procedia Social and Behavioral Sciences, 2, 682-687. 